\title{
Attachment to the Amazon Rainforest: Constitutive Aspects and their Predictors
}

\author{
Daniele da Costa Cunha Borges Rosa ${ }^{1}$ \\ Maria Inês Gasparetto Higuchi² \\ Antonio Roazzi ${ }^{3}$
}

\begin{abstract}
This investigation aims to contribute to the understanding of the attachment to the Amazon rainforest and its predictors, considering the dimensions that characterize this extensive environment. Five instruments were administered to 333 individuals of both genders, over the age of 18, from the cities of Ceres and Manaus, evaluating the Ecological affinity profile; Attachment to the Amazon rainforest; Experiences in nature; Knowledge of the Amazon rainforest; and Socioeconomic factors. The results confirm that attachment depends on the length of stay in the place. Data shows that the ecological affinity profile plays an important role in the attachment to a natural environment, suggesting that this relationship is strengthened by understanding the characteristics of this environment and its experiences. Based on the perspective of Environmental Psychology, this study advances knowledge on place attachment predictors and provides important arguments for the development of pro-environmental interventions focused on emotional and experiential aspects.
\end{abstract}

Keywords: environmental psychology, amazon rainforest, attachment behavior

\section{Apego à Floresta Amazônica: Aspectos Constitutivos e seus Preditores}

\begin{abstract}
Resumo: Este estudo visa contribuir com o entendimento acerca do apego à floresta amazônica e seus preditores considerando as dimensões características deste macro ambiente. Cinco instrumentos foram aplicados a 333 indivíduos de duas cidades brasileiras, de ambos os sexos, com idade superior a 18 anos: Afinidade ecológica; Apego à floresta amazônica; Experiências na natureza; Conhecimento da floresta amazônica; e socioeconômico. Os resultados confirmam que o apego depende fortemente do tempo de permanência no lugar. O perfil de afinidade ecológica é importante para o apego ao ambiente natural e esta relação é fortalecida com conhecimento das características deste ambiente e das vivências. Este estudo acrescenta evidências para o entendimento dos preditores do apego ao lugar e provê argumentação para o desenvolvimento de intervenções pró-ambientais focadas nos aspectos emocionais e experienciais.
\end{abstract}

Palavras-chave: psicologia ambiental, floresta amazônica, comportamento de apego

\section{Apego a la Selva Amazónica: Aspectos Constitutivos y sus Predictores}

\begin{abstract}
Resumen: En este trabajo se pretende comprender el apego a la Selva Amazónica y sus predictores teniendo en cuenta las dimensiones características de este entorno macro. Se administraron a 333 individuos de ambos sexos, mayores de 18 años de edad de dos ciudades brasileñas, las siguientes pruebas: Perfil de afinidad ecológica; Apego a la selva amazónica; Experiencias en la naturaleza; Conocimiento del bioma; y un perfil socioeconómico. Los resultados confirmaron que el apego depende fuertemente de la duración de la estancia en el lugar. Además, el perfil de afinidad ecológica es importante para el apego al medio ambiente natural y esta relación se fortalece a partir del conocimiento de las características de este entorno y las experiencias. Este estudio aporta evidencia para la comprensión de los predictores de apego al lugar y proporciona argumentos para desarrollar intervenciones proambientales centradas en aspectos emocionales y vivenciales.
\end{abstract}

Palabras clave: psicología ambiental, selva amazónica, comportamiento de apego

\footnotetext{
'Universidade Federal de Roraima, Boa Vista-RR, Brazil

2Instituto Nacional de Pesquisas da Amazônia, Manaus-AM, Brazil

${ }^{3}$ Universidade Federal de Pernambuco, Recife-PE, Brazil
}

This article is derived from the doctoral thesis by Daniele Rosa under the supervision of Antonio Roazzi at the Postgraduate Program in Cognitive Psychology- Universidade Federal de Pernambuco. We thank the Amazonas Research Support Foundation (FAPEAM) for assisting, through Ed. 15/2014, the translation of this manuscript.

Correspondence address: Daniele da Costa Cunha Borges Rosa. Universidade Federal de Roraima. Av. Cap. Ene Garcês, n 2413 - Aeroporto, Boa VistaRR, Brazil. CEP 69.310-000. E-mail: daniele.costa.cunha@gmail.com
Place attachment is a bonding between people and the environments that are meaningful to them (Bailey, Devine-Wright, \& Batel, 2016; Giuliani, 2003). Fischer (1994) defines place attachment as a tangible geographical delimitation to a territory of social use. In general, the literature is concerned with attachment to microenvironments that comply with such designation; but how do we establish an emotional attachment to macroenvironments, whose boundaries are discontinuous and permeated by diverse symbolic understandings - as in the case of the Amazon rainforest? What are the aspects of 
this affective bond? What predictors are related to it? These questions are the focus of this study.

In their theoretical proposal, Scannell and Gifford (2010) describe place attachment as a three-dimensional construct, incorporating person, place, and psychological process. In the "person" dimension, attachment is defined at both individual and group level. For these authors, the attachment is mostly manifested in relation to places that evoke memories, personal stories; that were the stage of important events that contributed to developing a sense of self or belonging.

The dimension concerned with place is considered by Scannell and Gifford (2010) as the most important. Although studied at different scales (home, neighbourhood, city, world) and proximities (local or global) (Lewicka, 2011b), the concept of place embraces not only a physical space, but also a social space.

Most studies addressing the attachment to the social aspects of a place found the people-place relationship to be a crucial factor to the attachment (Plunkett, Phillips, \& Kocaoglu, 2018). These proposals identified attachment based on the representativeness of that place for a group, proving that a place can function as a significant space of social interactions and as a social symbol - such as occurs with patriotism or the rivalry between countries and neighbourhoods, respectively (Devine-Wright \& Batel, 2017; Hidalgo \& Hernández, 2001). Although less prominent in the literature, the physical dimension contributes in a special way for the occurrence of place attachment.

When evaluating the notion of dependency of place, one may pinpoint diverse material aspects that provide for people's needs in terms of shelter, food, safety, and leisure. Place attachment can also be manifested in a non-specific manner; for example, a person can be either attached to nature in general, without establishing clear boundaries, or to a specific locality, which does not necessarily imply emotional bonds to other natural environments. Despite the focus on physical dimensions, psychosocial and cultural principles also explain why these place-related aspects are considered meaningful to a person or a group. According to Scannell and Gifford (2010), the bond between individuals (or groups) and places (physical or social, natural or built) accounts largely for this subjective dimension - it is the affection and knowledge arising from lived experiences.

Being a relationship exclusively sentimental established with places, affection occupies a central role within place attachment. Pride, wellbeing, love, fear, longing, and sadness are some of the emotions related to meaningful places in a person's story. These affections can be positive, negative, or ambivalent, comprising constituent parts of the relations with physical spaces and defining an individual's longing for being close to a particular place (Scannell \& Gifford, 2017; Shin, 2016).

Attachment also includes cognitive aspects, such as beliefs, values, attitudes, schemes, knowledge, and memories related to a given place. According to the theories that we develop about the world, by conceptualizing a place, we categorize it into familiar or strange, favorite or indifferent, trivial or valuable. Such categorization indicates the components responsible for attachment to specific environments (Scannell \& Gifford, 2010).

Another psychological aspect inherent to this individualplace relationship is behavioral, whereby attachment is typified by actions of maintenance and proximity towards the place. Studies have shown that people who spend a long time far from their homes, cities, or countries often feel like returning, even as visitors (Morse \& Mudgett, 2017). More recently, neuroscience found evidence that place constitutes a distinct dimension in neuronal processing, identifying many neurobiological correlates of phenomenological observations concerning sense of place. In fact, the human brain comprises specific and specialized structures and processes to perceive, memorize, link, assess, and use spatial information (Lengen \& Kistemann, 2012).

Such attachment is expressed, for example, when people choose to stay in areas of risk, or even avoiding or denying interesting offers of work before the need to leave these places (Riemer, 2004). The behavioral dimension of attachment is confirmed upon the reconstruction of places after a natural disaster, the transformation of new significant places of housing, and the acknowledgement of the desire to stay in a place (Lee \& Evans, 2020; Merdjanoff, 2013).

In sum, Scannell and Gifford (2010) developed and instrument that conceives place attachment as a bonding between an individual (or a group) and a place, which may vary depending on its specificities and social aspects. Moreover, the functionality, symbolism, and the capacity to encompass relationships are aspects of place attachment that emerge from cognitive, affective, and behavioral experiences over time (Breitenbecher \& Fuegen, 2019).

Considering the above exposed, this study investigates the possibility of situating the Amazon rainforest as a social symbol for diverse groups, such as Brazilians, Amazonians, and environmentalists, seeking to understand whether the forest can be a locus of personal and collective stories that represent the sense of identity and self. The aforementioned assumptions allow us to verify that affections, knowledge, and behavior integrates the construct of place attachment. But what roles does this attachment play?

The literature often assigns three roles for place attachment: survival and security, self-regulation, and temporal or personal continuity. People and groups are bound to places that provides for their survival needs, such as food, shelter, water, housing, and products and services (Giuliani, 2003). When referring to a geographic territory belonging to a macro-space, this may be the case of the representation of the Amazon rainforest for some individuals. Places may also be the subject of attachment due to their restorative qualities, regularly attributed to natural environments (Payne, Loi, \& Thorsteinsson, 2020), and / or because they are deemed as optimal places for performing certain activities or meeting established goals and needs (Moulay, Ujang, Maulan, \& Ismail, 2018).

Place attachment likewise contributes to self-continuity; that is, the place represents a connection between a 
meaningful past and the future for an individual or a group. Places also evoke a sense of belonging, constituting the personal, social or collective identity. In this sense, the attachment to a given place indicates the type and degree of the relationship established between a person and that environment (Scannell \& Gifford, 2017).

Besides its dimensions, the predictors of place attachment also demand attention. As the procedural dimension of place attachment is still not well defined, studies on the theme show that some dimensions may overlap with its predictors and vice-versa (Lewicka, 2011b). In a literature review conducted by Lewicka (2011b), the author finds the main predictors of attachment to be the length of stay within the place and the ensuing social bonds. Variables such as age, income, gender, education, and physical characteristics of the place are erratic, so that studies found both positive and negative relationships according to the type of attachment.

Such bonding functions as a predictor of actions focused on the place of attachment (Devine-Wright \& Batel, 2017; Scannell \& Gifford, 2010), besides being related to psychosocial aspects such satisfaction with life as a whole, greater care with family ties, and consolidation of social ties (Lewicka, 2011a). These findings indicate that place attachment is associated with a specific psychosocial profile, despite the lack of defined directions of causality.

For the purposes of this study, we deemed relevant relating place attachment with variables that indicate an ecological affinity profile, (Rosa, Roazzi \& Higuchi, 2015); that is, psychosocial characteristics related to positive evaluations of the nature. Previous studies on the theme valued the personal dimension much more than physical dimensions. As proposed by Rosa, Roazzi and Higichi (2015), this study uses the three dimensions of attachment to forests. The first one refers to dependency of place, whereby the forest is understood as both the provider of resources and a favorable environment to achieve personal goals, thus suggesting the need for proximity. The second dimension deals with the identification with place, addressing the congruence between the individual and the environment. According to this dimension, the forest is a place for admiration, thus suggesting a longing for proximity. Finally, the third dimension refers to the forest as a social symbol, a comprehensive environment that fosters pride and representativeness to a social group.

Our study aims to advance knowledge about the understanding of the attachment to the Amazon rainforest, investigating its predictors and considering the dimensions that characterize this extensive environment.

\section{Method}

\section{Participants}

This study was conducted with 333 young adults $(F=243 ; M=90), 155(46.5 \%)$ of whom resided in Manaus, Amazonas, and 178 (53.5\%) in Ceres, Goiás. All participants were university students, being $150(45 \%)$ in Earth sciences or related subjects (biology, forest engineering, and agronomy) and $183(55 \%)$ in other areas (psychology, pedagogy, nursing, and chemistry). Through a convenience sampling methodology, all participants present in the classroom at the time of data collection who agreed to participate by signing an informed consent form were included in the study.

Regarding marital status, 248 (74.5\%) participants declared themselves as being single, 79 (23.8\%) married, and five (1.5\%) divorced. Socioeconomic status was measured by household income and reported in minimum wages, with 107 (32.6\%) participants reporting an income of up to two minimum wages, $118(36 \%)$ from two to five, $66(20.1 \%)$ from five to ten, and $37(11.3 \%)$ more than ten minimum wages - data that reflects the reality of income distribution in the country.

Most participants declared themselves as being either Catholic $(N=179 ; 54.7 \%)$ or evangelical $(N=101 ; 30.9 \%)$, but the sample also included participants that reported following no faith $(N=27 ; 8.3 \%)$, spiritists $(N=10 ; 3.1 \%)$, or atheists $(N=10 ; 3.1 \%)$.

\section{Instruments}

Five methodological tools were used in this study:

Profile of Ecological Affinity (PAE) - elaborated from diverse instruments evaluating peoples' response to environmental questions, such as the Inclusion of Nature in the Self Scale (INS) (Schultz, 2001); Connectedness to Nature Scale (CNS) (Mayer \& Frantz, 2004) adapted; Forest Values Scale (FVS) (Steel, List, \& Shindler, 1994); and the Consideration of Future Consequences Scale (CFC) (Strathman, Gleicher, Boninger, \& Edwards, 1994).

Inclusion of Nature in the Self(INS) - a one-dimensional scale that graphically measures the self-nature connection through seven circles that are either unified or separated according to the feeling of connection between the individual and nature (Schultz, 2001);

Connectedness to Nature Scale (CNS) - a 14-item scale that evaluates the levels of connectedness to nature (Mayer \& Frantz, 2004) and was validated in Brazil by Rosa, Roazzi and Higuchi (2015). The coefficient of the sampling adequacy test (Kaiser-Meyer-Olkin) was 0.90, Bartlett's sphericity test: $\chi 2=1093.28 ; \mathrm{gl}=55 p \leq 0.001$. Moreover, Cronbach's alpha for one factor reached values of 0.85 for internal consistency.

Forest Values Scale (FVS) - a two-dimensional scale that identifies ecocentric (FVS ecocentric) and anthropocentric values (FVS anthropocentric) in relation to forests (Steel et al., 1994). It was validated in Brazil by Rosa, Roazzi and Higuchi (2015), and presents a coefficient of sampling adequacy (Kaiser-Meyer-Olkin) equal to 0.67 , Bartlett's sphericity test: $\chi^{2}=457.600 ; \mathrm{gl}=28 p \leq 0.001$. Regarding internal consistency, Cronbach's alpha reached a coefficient of 0.76 for ecocentric values and of 0.51 for anthropocentric values.

Consideration of Future Consequences Scale (CFC) - a two-dimensional scale that identifies the orientation of the individual in relation to time; that is, whether they are 
concerned with the future or focused on the immediate present (Strathman et al., 1994). This instrument was adapted to the Brazilian context by Rosa, Roazzi, and Higuchi (2015), and presents a coefficient of sampling adequacy (Kaiser-MeyerOlkin) equal to 0.77; Bartlett's sphericity test: $\chi 2=585.120$; $\mathrm{gl}=66 \mathrm{p} \leq 0.001$. Regarding internal consistency, Cronbach's alpha reached a coefficient equal to 0.53 for concerns with the future and 0.69 for the present.

Experiences in Nature (VIN) - refers to a scale developed and validated by Rosa, Roazzi, and Higuchi (2015) to verify the human-nature relationship based on two dimensions: Unspecified Experiences in Nature and Experiences of Immersion in the Forest. The scale comprises ten statements regarding human involvement with nature owing to workrelated and leisure activities, to which the participant must assign a score ranging from one (never) to five (always). The coefficient of sampling adequacy (Kaiser-Meyer-Olkin) was equal to 0.73; Bartlett's sphericity test: $\chi 2=926.169 ; \mathrm{gl}=$ $36 \mathrm{p} \leq 0.001$. Regarding internal consistency, Cronbach's alpha reached coefficients equal to 0.74 for Unspecified Experiences in Nature and 0.78 for Experiences of Immersion in the Forest.

Knowledge of the Amazon Rainforest (CFA) - a 19-item scale that measures the different levels of knowledge about the Amazon rainforest based on true, false, and "I don't know" responses. This instrument was developed based on technical assumptions raised by the fields of Geography, Forestry Engineering, and Ecology, and validated by specialist consultants. The knowledge about the Amazon rainforest is determined by the number of correct answers.

Attachment to the Amazon Rainforest (AFA) - a 20item Likert scale developed and validated by Rosa, Roazzi, and Higuchi (2015) to measure the level of attachment to the Amazon rainforest according to three dimensions: (a) Dependency of place, which refers to the understanding that the forest is an environment with physical and social characteristics that, when compared to other environments, provide optimum conditions for conducting certain activities; (b) Identification with the place, which refers to a process that motivates a set of beliefs and pleasant emotions towards a specific environment, suggesting attachment and connection, but unrelated to the individual's identity; and (c) Social Symbol, which suggests an attachment to a macroenvironment not directly associated with an individual history, but with a cultural history. The coefficient of sampling adequacy (Kaiser-Meyer-Olkin) was equal to 0.90; Bartlett's sphericity test: $\chi^{2}=2759,573 ; \mathrm{gl}=136 \mathrm{p} \leq 0.001$. As for internal consistency, Cronbach's alpha reached coefficients equal to 0.90 for Dependency of place, 0,87 for Identification with the place, and 0.73 for Social Symbol.

Socioeconomic profile (PSE) - a questionnaire composed of open and closed questions that seeks to characterize the sample based on sociodemographic variables considered important in defining the different types of relationship and understandings regarding the Amazon rainforest, namely: age, sex, income, education level, marital status, religiosity, and involvement with political parties.

\section{Procedure}

Data collection. All instruments used in this study were self-administered and performed in the classroom environment; the average response time was 30 minutes.

Data analysis. Data were analyzed using simple descriptive statistics and inferential univariate and multivariate analysis, including exploratory factor. The ecological affinity profile and structural organization among different dimensions and sociodemographic variables were assessed by means of a nonmetric multidimensional Similarity Structure Analysis with "external variables as points technique" (Roazzi \& Dias, 2001). Stepwise regressions were also computed.

\section{Ethical Considerations.}

This study was approved by the Ethics Committee of the Universidade Federal de Pernambuco. under protocol number 514.731/2014. Data was collected in higher education institutions, following all due ethical requirements.

\section{Results}

\section{Multiple regression}

Stepwise regressions determined the level of correlation between the independent variables of the Profile of Ecological Affinity (PAE), Experiences in Nature (VIN), and Knowledge of the Amazon rainforest (CFA) instruments, as well as of the three dimensions of the Attachment to Forest (AFA), considered as dependent variables (Table 1).

Regarding dependent variables, the regression model verified a significant association between the attachment dimension Dependency of place and Experiences of Immersion in the Forest, explaining the largest variation (32.2\%). This dimension was also associated with Profile of Ecological Affinity (2.9\%) and Knowledge of the Forest (1.5\%), whereas Unspecified Experiences of Nature did not comprise a significant predictor. Therefore, the model explained 35.9\% of the total variance, considered as median. These findings indicate the need for empirical bases to discuss the association between Dependency of place and these variables.

As for Identification with the place, the model verified significant associations between all independent variables. While the Profile of Ecological Affinity explained most of the variation (31.4\%), Experiences of Immersion in the Forest, Knowledge of the Forest, and Unspecified Experiences of Nature explained $41.4 \%$ of the variance, accounting for $7.0 \%, 1.9 \%$, and $1.2 \%$, respectively.

Finally, the regression model only verified significant associations between the variable Social Symbol and the Profile of Ecological Affinity, explaining 5.2\% variation. These results allow us to assess the association between these independent variables and place attachment, although prediction accuracy may vary according to the dimension being considered. 
Rosa, D. C. C. B., Higuchi, M. I. G., \& Roazzi, A. (2021). Attachment to the Amazon Rainforest.

Table 1

Stepwise regressions considering Ecological Affinity Profile, Unspecified Experiences in Nature, Experiences of Immersion in the Forest, and Knowledge of the Amazon Rainforest as independent variables; and the three dimensions of the Attachment to the Amazon Rainforest as dependent variable, namely: Dependency on place, Identification with the Place and Social Symbol

\begin{tabular}{|c|c|c|c|c|c|c|c|}
\hline Model & $R$ & $R^{2 \text { adjusted }}$ & $R^{2 \text { ch }}$ & $F^{\mathrm{ch}}$ & $d f^{1}$ & $d f^{2}$ & $p$ \\
\hline \multicolumn{8}{|l|}{ DV Dependency on place } \\
\hline Experiences of Immersion in the Forest & .567 & .320 & .322 & 137.22 & 1 & 289 & .001 \\
\hline Ecological Affinity Profile & .592 & .346 & .029 & 12.79 & 1 & 288 & .001 \\
\hline Knowledge of the Amazon Rainforest & .604 & .359 & .015 & 6.61 & 1 & 287 & .011 \\
\hline \multicolumn{8}{|l|}{ DV Identification with the Place } \\
\hline Ecological Affinity Profile & .562 & .314 & .316 & 136.44 & 1 & 295 & .001 \\
\hline Experiences of Immersion in the Forest & .626 & .387 & .075 & 36.40 & 1 & 294 & .001 \\
\hline Knowledge of the Amazon Rainforest & .641 & .405 & .019 & 9.42 & 1 & 293 & .002 \\
\hline Unspecified Experiences in Nature & .650 & .414 & .012 & 5.82 & 1 & 292 & .016 \\
\hline \multicolumn{8}{|l|}{ DV Social Symbol } \\
\hline Ecological Affinity Profile & .234 & .052 & .055 & 16.982 & 1 & 293 & .001 \\
\hline
\end{tabular}

\section{Multidimensional Scaling Analysis: SSA}

The attachment dimensions and variables considered as indicators of attachment were analyzed using the Similarity Structure Analysis (SSA) (Roazzi \& Souza, 2019). For that, the Profile of Ecological Affinity was determined based on the combination of the following scales:

(a). Inclusion of Nature in the Self (INS): a onedimensional scale that graphically measures the self-nature connection, as shown in the figure below (Schultz, 2001);

(b). Connectedness to Nature Scale (CNS): a 14-item scale that evaluates the levels of connectedness to nature (Mayer \& Frantz, 2004) and was validated in Brazil by Rosa, Roazzi and Higuchi (2015).

(c). Forest Values Scale (FVS): a two-dimensional scale that identifies ecocentric (FVS ecocentric) and anthropocentric values (FVS anthropocentric) in relation to forests (Steel et al., 1994), validated in Brazil by Rosa, Roazzi and Higuchi (2015).

(d). Consideration of Future Consequences (CFC): a two-dimensional scale that identifies the orientation of the individual in relation to time; that is, whether they are concerned with the future (CFC Future) or focused on the immediate present (CFC Immediate). This instrument was developed by Strathman et al. (1994) and adapted to the Brazilian context by Rosa, Roazzi, and Hi-guchi (2015).

(e). Experiences in Nature (VIN): a scale developed by Rosa, Roazzi, and Higuchi (2015) and characterized by two dimensions, namely Unspecified Experiences in Nature (VIN Unspecified) and Experiences of Immersion in the Forest (VIN Immersion).
For a more specific and thorough understanding of the structure, each of these profile elements is separately presented in Figure 1.

Our results indicate an association between the variables assembling the Profile of Ecological Affinity, Environmental Experiences (both in the forest and in the nature), and Knowledge of the Forest and the three dimensions of attachment, located in the upper left of the map shown in Figure 1. However, these dimensions differ from each other.

The Social Symbol dimension is closer to the ecocentric values and connectedness with nature, but further away from other attachment dimensions and experiences in nature. In turn, Identification with the place is closer to the sense of inclusion of nature in the self, considerations of future consequences, and unspecified experiences of nature.

Dependency of place showed the higher levels of knowledge about the Amazon biome, specific experiences in the forest, and the sense of inclusion of nature in the self. These findings indicate that, although all pertaining to a major dimension of attachment, identification and dependency are more similar to each other, whereas Social symbol figures at the margin.

We verified a close relationship between older, married, and male participants with the three dimensions of attachment. Participants residing in Manaus showed more proximity with the indicators of attachment, especially dependency of place. However, participants from Ceres were likewise close to identification with the place and social symbol. Participants who were younger and of the female gender were opposite to the three dimensions of attachment. 


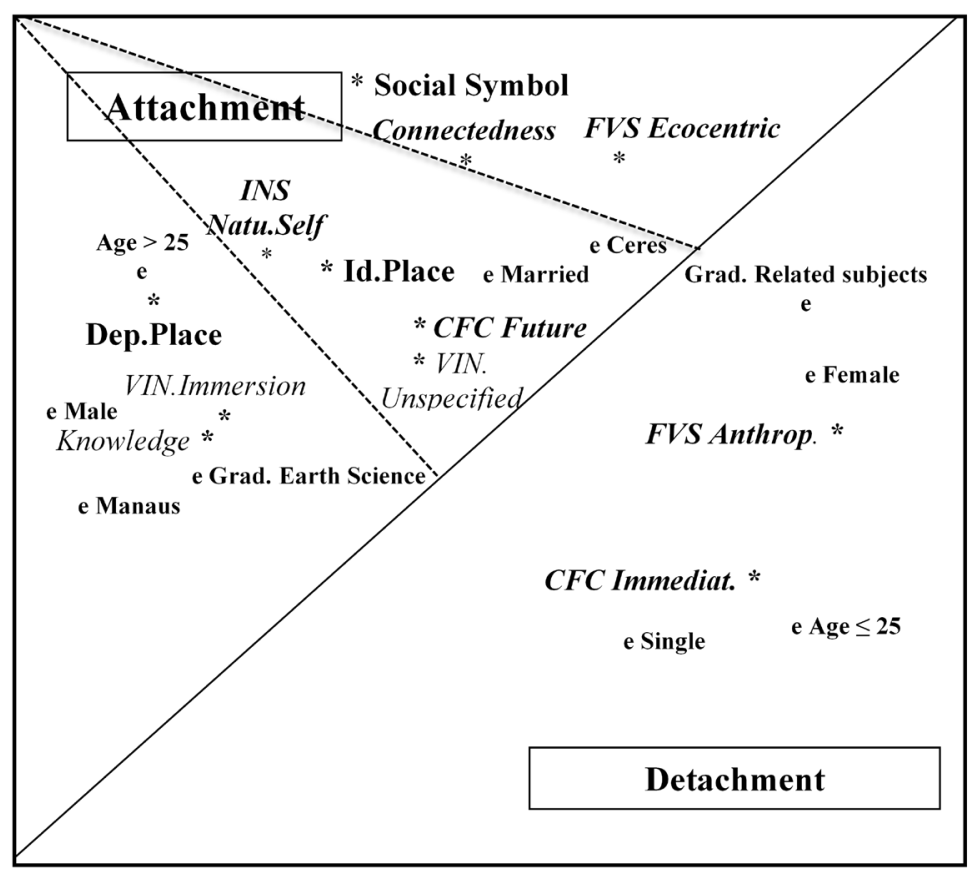

Figure 1. SSA (Monotonicity Coefficient) of the "Attachment to the Amazon Rainforest Scales - AAF" (three dimensions: "Dependency on place", "Identification with the Place" and "Social Symbol"), "Consideration of Future Consequences Scale CFC" (two dimensions: CFC Future and CFC Immediate), "Connectedness to Nature" (Connectedness), "Forest Value Scale FVS" (two dimensions: FVS Ecocentric and FVS Anthropocentric), "Inclusion of Nature in the Self - INS" (Natu.Self), "Experiences in Nature - VIN." (two dimensions: Unspecified Experiences in Nature - VIN.Unspecified and Experiences of Immersion in the Forest- VIN.Immersion), and "Knowledge of the Amazon Rainforest" (Knowledge), with the following external variables (e) City (two: Manaus and Ceres), Age Range (2: $\leq 25$ and $>25$ years), Graduation (Grad) (2: Earth Science Grad. Earth Science and Grad. Unrelated subjects) and Marital Status (2: Single and Married). Coordinate 1x2 of the 3D solution (Coefficient of alienation 0.0688).

\section{Discussion}

According to the literature, the occurrence of place attachment requires proximity. However, before the extensive environment of the Amazon rainforest, such attachment may be related to different dimensions and occur at different levels. The dimension of Dependency to place depends on the indivdual's experience in the Amazon rainforest, knowledge about this environment, and ecological affinity profile. These relationships elucidate the attachment function within this dimension, as individuals and groups may feel bonded to places that provide for their survival needs (Giuliani, 2003) and / or are considered optimal for performing certain activities and achieving their goals and desires (Moulay et al., 2018). Such assumption is confirmed by the association of this dimension with the residents of Manaus.

Dependency of place was associated with Experiences of Immersion in the Forest and high levels of Knowledge about its Functioning, suggesting that this process implies the recognition of characteristics that are important for people to survive or meet their goals. The fact that this dimension is related to undergraduate students in earth science confirms this attachment function.

Identification with the place refers to the belief that the forest comprises a significant environment that evokes pleasant emotions and suggests bonding. Different from what was previously assumed, this dimension is intrinsically associated with experiences of immersion in the nature (Smith, Dunhill, \& Scott, 2018), as well as with unspecified experiences - that is, the person-place identification process requires experiences in the forest and in other natural environments. The results of the analysis of similarities show that Identification with the place approaches the Inclusion of Nature in the Self, being the most associated dimension with Considerations of Future Consequences - thus explaining its expressive association with the Ecological Affinity Profile.

One of the functions of attachment is the Continuity of the Self, which implies that places representing a 
connection between meaningful past and future moments evoke a feeling of belonging and shape the personal and social identity. The association between the Inclusion of Nature in the Self, Considerations of Future Consequences, and the Identification with the place suggests that the latter considers the aforementioned attachment only partially. This means to say that feeling that nature is part of you does not necessarily imply that you are part of nature, or at least that this relationship cannot be extrapolated for a specific environment such as the Amazon rainforest. Nature is a part of the self; but the Amazon forest does not represent an environmental identity. Further studies may investigate whether the person-place identification process is related to a general sense of inclusion of nature in the self rather than to specificities of the place of attachment.

Considerations of Future Consequences were likewise associated with the Identification with the place, suggesting that place represents a connection between past and future. This understanding is associated with the sense of Continuity of the Self, which is promoted by environments such as the Amazon rainforest and perceived by those oriented towards the future.

Due to its approximation to ecocentric beliefs and connection with the nature, the Social symbol dimension suggests a different type of attachment to the Amazon rainforest (AFA). We also verified a significant association between this dimension and the ecological affinity profile, despite of its minimal explanatory potential. Worth mentioning, we did not envisage this dimension while preparing the data collection instruments used in this study, nor did we find it in the literature review. This can either indicate an inadequacy of its composing items or a specific attachment to macro-environments, more conceptual than experiential. Regardless, when understanding place attachment as an affective bond between people and places in a globalized world mediated by virtual approximation technologies, we may reasonably assume the existence of relationships of attachment to macroenvironments that may have never been visited personally.

Considering the exposed, we suggest further studies to refine the instruments to measure forest attachment by adding more diversified items aiming to improve its construct validity.

Besides evaluating the association among indicators of attitudes towards the Amazon rainforest and the different dimensions of attachment, this study also investigated the correlation between these dimensions and sociodemographic variables such as age, gender, marital status, and religion, verifying a greater correlation with variables related to the Ecological Affinity profile than with other dimensions. In a previous study conducted by Rosa, Roazzi \& Higuchi (2015) that waived the use of the Attachment to the Forest instrument, the structure and location of these sociodemographic variables had the same presentation as in our study - except for place of residence, where participants from Manaus showed a closer association to attachment. These results corroborate the literature on place attachment (Lewicka, 2011b), which emphasizes immersion experiences and the time spent in the environment as important factors for the attachment process. Moreover, the authors report that such environmental bonding is particularly significant when the dependency of place is considered.

Such strong correlation between place attachment and length of stay, reported in previous studies, is validated by our findings. Such strong correlation between place attachment and length of stay, reported in previous studies, is validated by our findings. Moreover, the ecological affinity profile shows to play an important role for the occurrence of attachment to a natural environment, besides suggesting that such relationship is strengthened according to the levels of knowledge about its characteristics and the experiences in it potential factors for improving psychosocial wealth.

\section{Limitations of the study}

This study has some limitations as to its methodology, such as the use of a convenience sample restricted to university students, which may incur bias. Further studies conducted with different social groups and macroenvironments can elucidate the dimensions of attachment to these environments in a more elucidative manner.

\section{Implications of the study}

From the perspective of Environmental Psychology, our results can be applied in the development of public policies and guidelines for environmental education, promoting interventions targeting socially significant experiences and ecological restoration for enabling the development and restructuring of attachment relationships between people and nature. This study is aligned with the literature on the theme (Braun \& Dierkes, 2017; Rosa, Profice, \& Collado, 2018), shifting the focus of environmental interventions towards both a cognitive and experiential and affective dimension, considering individuals in their entirety and preventing behavioral inertia (Gifford \& Chen, 2017; Gifford \& Nilsson, 2014).

Children's experiences with nature evince its role as both a promoter of healthy development and a strong predictor of care and protection towards nature - which is especially relevant before the recurring environmental problems (Izenstark \& Ebata, 2016; Louv, 2016; Otto \& Pensini, 2017). Different studies show the benefits arising from being close to nature and its association with proenvironmental behaviors (Nisbet, 2014; Richardson, Hallam, \& Lumber, 2015).

Listed as a world heritage ecological site and considered an important symbol, the Amazon rainforest demands greater political and social attention not only due to its ecological characteristics, but also due to the quality of life it provides to people - whether they are its residents or not. Therefore, this study highlights its importance for the psychosocial and cultural aspects of the locals. To this end, activities aimed at deepening knowledge about this ecosystem and experiences of affective immersion with the nature are promising 
educational possibilities. Considering that the establishment of affective bonds with nature is a process initiated during childhood, including proximity to nature in the day-to-day life of children is a fruitful path.

\section{References}

Bailey, E., Devine-Wright, P., \& Batel, S. (2016). Using a narrative approach to understand place attachments and responses to power line proposals: The importance of lifeplace trajectories. Journal of Environmental Psychology, 48, 200-211. doi:10.1016/j.jenvp.2016.10.006

Braun, T., \& Dierkes, P. (2017). Connecting students to nature - how intensity of nature experience and student age influence the success of outdoor education programs. Environmental Education Research, 23(7), 937-949. doi:10.1080/13504622.2016.1214866

Breitenbecher, K. H., \& Fuegen, K. (2019). Nature and exercise interact to influence perceived restorativeness. Ecopsychology, 11(1), 33-42. doi:10.1089/eco.2018.0056

Devine-Wright, P., \& Batel, S. (2017). My neighbourhood, my country or my planet? The influence of multiple place attachments and climate change concern on social acceptance of energy infrastructure. Global Environmental Change, 47, 110-120. doi:10.1016/ j.gloenvcha.2017.08.003

Fischer, G. (1994). Psicologia social do ambiente [Environmental social psychology]. Lisboa, Portugal: Instituto Piaget.

Gifford, R. D., \& Chen, A. K. S. (2017). Why aren't we taking action? Psychological barriers to climate-positive food choices. Climatic Change, 140(2), 165-178. doi:10.1007/s10584-016-1830-y

Gifford, R. D., \& Nilsson, A. (2014). Personal and social factors that influence pro-environmental concern and behaviour: A review. International Journal of Psychology, 49(3), 141-157. doi:10.1002/ijop.12034

Giuliani, M. V. (2003). Theory of attachment and place attachment. In M. Bonnes, T. Lee, \& M. Bonaiuto (Eds.), Psychological theories for environmental issues (pp. 137-170). Aldershot, United Kingdom: Ashgate.

Hidalgo, M. C., \& Hernández, B. (2001). Place attachment: Conceptual and empirical questions. Journal of Environmental Psychology, 21(3), 273-281. doi:10.1006/ jevp.2001.0221

Izenstark, D., \& Ebata, A. T. (2016). Theorizing family-based nature activities and family functioning: The integration of attention restoration theory with a family routines and rituals perspective. Journal of Family Theory \& Review, 8(2), 137-153. doi:10.1111/jftr.12138
Lee, B. A., \& Evans, M. (2020). Forced to move: Patterns and predictors of residential displacement during an era of housing insecurity. Social Science Research, 87, 102415. doi:10.1016/j.ssresearch.2020.102415

Lengen, C., \& Kistemann, T. (2012). Sense of place and place identity: Review of neuroscientific evidence. Health \& Place 18(5), 1162-1171. doi:10.1016/j. healthplace.2012.01.012

Lewicka, M. (2011a). On the varieties of people's relationships with places: Hummon's typology revisited. Environment and Behavior, 43(5), 676-709. doi:10.1177/0013916510364917

Lewicka, M. (2011b). Place attachment: How far have we come in the last 40 years? Journal of Environmental Psychology, 31(3), 207-230. doi:10.1016/j.jenvp.2010.10.001

Louv, R. (2016). A última criança na natureza: Resgatando nossas crianças do transtorno do déficit de natureza [The last child in nature: Rescuing our children from the deficit of nature disorder] (A. Azuma \& C. Belhassof, Trans.). São Paulo, SP: Aquariana.

Mayer, F. S., \& Frantz, C. M. (2004). The connectedness to nature scale: A measure of individuals feeling in community with nature. Journal of Environmental Psychology, 24(4), 504-515. doi:10.1016/j.jenvp.2004.10.001

Merdjanoff, A. A. (2013). There's no place like home: Examining the emotional consequences of Hurricane Katrina on the displaced residents of New Orleans. Social Science Research, 42(5), 1222-1235. doi:10.1016/ j.ssresearch.2013.04.004

Morse, C., \& Mudgett, C. (2017). Longing for landscape: Homesickness and place attachment among rural outmigrants in the 19th and 21st centuries. Journal of Rural Studies, 50, 95-103. doi:10.1016/j.jrurstud.2017.01.002

Moulay, A., Ujang, N., Maulan, S., \& Ismail, S. (2018). Understanding the process of parks' attachment: Interrelation between place attachment, behavioural tendencies, and the use of public place. City, Culture and Society, 14, 28-36. doi:10.1016/j.ccs.2017.12.002

Nisbet, E. K. (2014). Canadians connect with nature and increase their well-being: Results of the 2014 David Suzuki Foundation 30x30 Nature Challenge. Retrieved from https://davidsuzuki.org/wp-content/uploads/2017/09/ 2014-30x30-nature-challenge-results.pdf

Otto, S., \& Pensini, P. (2017). Nature-based environmental education of children: Environmental knowledge and connectedness to nature, together, are related to ecological behaviour. Global Environmental Change, 47, 88-94. doi:10.1016/j.gloenvcha.2017.09.009

Payne, E. A., Loi, N. M., \& Thorsteinsson, E. B. (2020). The restorative effect of the natural environment on university students' psychological health. Journal of Environmental and Public Health, 2020, 4210285. doi:10.1155/2020/4210285 
Plunkett, D., Phillips, R., \& Kocaoglu, B. U. (2018). Place attachment and community development. Journal of Community Practice, 26(4), 471-482. doi:10.1080/ 10705422.2018.1521352

Richardson, M., Hallam, J., \& Lumber, R. (2015). One thousand good things in nature: Aspects of nearby nature associated with improved connection to nature. Environmental Values, 24(5), 603-619. doi:10.3197/ $096327115 X 14384223590131$

Riemer, J. W. (2004). Job relocation, sources of stress, and sense of home. Community, Work \& Family, 3(2), 205-217. doi:10.1080/713658901

Roazzi, A., \& Souza, B. C. (2019). Advancing facet theory as the framework of choice to understand complex phenomena in the social and human sciences. In S. H. Koller (Ed.), Psychology in Brazil: Scientists making a difference (pp. 283-309). New York, NY: Springer.

Roazzi, A., \& Dias, M. G. B. B. (2001). Teoria das facetas e avaliação na pesquisa social transcultural: Explorações no estudo do juízo moral. In Conselho Regional de Psicologia - 13a Região PB/RN (Ed.), A diversidade da avaliação psicológica: Considerações teóricas e práticas (pp. 157-190). João Pessoa, PB: Idéia.

Rosa, D. C. C. B., Roazzi, A., \& Higuchi, M. I. G. (2015). PSICAMB - Perfil de Afinidade Ecológica: Um Estudo sobre os Indicadores da Postura perante a Natureza. Psico, 46(1), 139-149. https://doi.org/ 10.15448/1980-8623.2015.1.17415

Rosa, C. D., Profice, C. C., \& Collado, S. (2018). Nature experiences and adults' self-reported pro-environmental behaviors: The role of connectedness to nature and childhood nature experiences. Frontiers in Psychology, 9, 1055. doi:10.3389/fpsyg.2018.01055

Scannell, L., \& Gifford, R. (2010). Defining place attachment: A tripartite organizing framework. Journal of Environmental Psychology, 30(1), 1-10. doi:10.1016/ j.jenvp.2009.09.006

Scannell, L., \& Gifford, R. (2017). Place attachment enhances psychological need satisfaction. Environment and Behavior, 49(4), 359-389. doi:10.1177/0013916516637648

Schultz, P. W. (2001). The structure of environmental concern: Concern for self, other people and the biosphere. Journal of Environmental Psychology, 21(4), 327-339. doi:10.1006/jevp.2001.0227

Shin, J.-H. (2016). Toward a theory of environmental satisfaction and human comfort: A process-oriented and contextually sensitive theoretical framework. Journal of Environmental Psychology, 45, 11-21. doi:10.1016/ j.jenvp.2015.11.004

Smith, M. A., Dunhill, A., \& Scott, G. W. (2018). Fostering children's relationship with nature: Exploring the potential of Forest School. Education, 46(5), 525-534. doi:10.1080/03004279.2017.1298644
Steel, B. S., List, P., \& Shindler, B. (1994). Conflicting values about federal forests: A comparison of national and Oregon publics. Society \& Natural Resources, 7(2), 137-153. doi:10.1080/08941929409380852

Strathman, A., Gleicher, F., Boninger, D. S., \& Edwards, C. S. (1994). The consideration of future consequences: Weighing immediate and distant outcomes of behavior. Journal of Personality and Social Psychology, 66(4), 742-752. doi:10.1037/0022-3514.66.4.742

Daniele da Costa Cunha Borges Rosa is a Professor at the Universidade Federal de Roraima, Boa Vista-RR, Brazil.

Maria Inês Gasparetto Higuchi is a Senior Researcher at the Instituto Nacional de Pesquisas da Amazonia, ManausAM, Brazil.

Antonio Roazzi is a Professor at the Universidade Federal de Pernambuco, Recife-PE, Brazil.

\section{Authors' Contribution:}

All authors made substantial contributions to the conception and design of this study, to data analysis and interpretation, and to the revision and approval of the final version of the manuscript. All the authors assume public responsibility for content of the manuscript.

Associate Editor:

Wanderlei Abadio de Oliveira

Received: Apr. 17, 2020

1st Revision: Dec. 11, 2020

Approved: Apr. 02, 2021

How to cite this article:

Rosa, D. C. C. B., Higuchi, M. I. G., \& Roazzi, A. (2021). Attachment to the Amazon rainforest: Constitutive aspects and their predictors. Paidéia (Ribeirão Preto), 31, e3128.doi:https://doi.org/10.1590/1982-4327e3128 